\title{
ARGUMENTATIVE DELIBERATION AND THE DEVELOPMENT OF INTELLECTUAL HUMILITY AND AUTONOMY IN THE CLASSROOM
}

\author{
LEANDRO DE BRASI \\ King's College London, UK. Strand, WC2R 2LS, London. \\ leandro.de_brasiakcl.ac.uk
}

It is argued that argumentative deliberation, which involves the interpersonal exchange and evaluation of reasons and counter-reasons, is crucial for the generation of epistemic goods given that it helps us eradicate errors and neutralise biases. However, to reap argumentative deliberation's epistemic benefits, the deliberators seem to need to instantiate a certain intellectual character: in particular, to be intellectually humble and autonomous. Given that, it is argued that the educational system should foster the development of the intellectual virtues of humility and autonomy. Moreover, some pedagogical strategies and practices as to how this can be achieved in the classroom are offered.

Key words: Argumentative Deliberation; Intellectual Humility; Intellectual Autonomy; Education; Virtue Development.

Se arguye que la deliberación argumentativa, que involucra el intercambio y evaluación de razones y contra-razones, es crucial para la generación de bienes epistémicos dado que ayuda a erradicar errores y neutralizar sesgos. Sin embargo, para tomar ventaja de los beneficios epistémicos de la deliberación argumentativa, pareciera que los deliberadores requieren instanciar un cierto carácter intelectual: en particular, necesitan ser intelectualmente humildes y autónomos. Dado esto, se arguye que el sistema educacional debe fomentar el desarrollo de las virtudes intelectuales de humildad y autonomía. Además, algunas estrategias y prácticas pedagógicas relacionadas a esta formación en la sala de clase son ofrecidas.

Palabras clave: Deliberación Argumentativa; Humildad Intelectual; Autonomía Intelectual; Educación; Formación de Virtudes. 


\section{Introduction}

We live in societies with hyper-specialised knowledge, which distribute the acquisition of knowledge among different people. Minimally, given that no one can know everything (or that much, for that matter) and our social cooperative nature, we would expect much epistemic interdependence among ourselves. Indeed, our pervasive testimonial practice (i.e. the transmission of information from one party to another) corroborates such dependence. Much of the knowledge we acquire throughout our lives is through such testimonial exchanges. ${ }^{1}$ But taking our epistemic interdependence seriously isn't just a matter of acknowledging our testimonial practice, it also means recognising the more complex practices found in our division of epistemic and cognitive labour that are not reducible to transmitting knowledge. ${ }^{2}$ We not only share information but also act as epistemic trainers and collaborators, among other things. For example, some people enable one to calibrate and fine-tune one's epistemic standards and practices and some work together with one to produce some knowledge, reasonable belief or some other epistemic good.

So it is a mistake to take information sharing as exhausting the forms of epistemic dependence to which our beliefs are subjected (Goldberg, 2011; Pritchard, 2015; Townley, 2011). And, importantly for present purposes, we need to notice that we also depend on others for the generation of epistemic goods. This is perhaps most clearly appreciated in scientific researchers' collaborations, but collaborative epistemic work, where people jointly perform same task (as opposed to work being delegated), certainly goes beyond science. Such social collaborative arrangements

\footnotetext{
1 Contrary to Descartes (1984), who accepts an extreme version of epistemic autonomy (e.g. AT VI 9, 17), where it's only one's own epistemic achievement that can render some belief knowledge, and only for oneself, other modern thinkers, such as David Hume (1975) and Thomas Reid (2010), understood the importance of our testimonial practice. Recently, much contemporary social and feminist epistemology makes emphasis on the social aspects of knowledgeyielding practices (De Brasi, 2017).

2 By the division of epistemic labour, I mean the distribution of cognitive work across people to separately perform distinct epistemic tasks required for some positive epistemic status, such as being justified or knowledge. Of course, the most familiar example of this delegation of labour is testimony: the speaker and the hearer perform different but complementary tasks (i.e., competent inquiry regarding some fact and legitimate acceptance of what is said, respectively) in order for the hearer's testimonially-based belief to be justified or knowledge. However, the division of epistemic labour not only concerns the transmission of epistemic goods, such as beliefs with positive epistemic status. For example, this division of labour often takes place with regard to the procedures for arriving at beliefs, say within science (since often one isn't aware of the rationale behind them and is implicitly trained to use them; De Brasi, 2015). By the division of cognitive labour, I mean the distribution of cognitive work across people to jointly perform a given epistemic task required for some positive epistemic status. One instance of this is interpersonal argumentative deliberation that often takes place within formal and informal groups, where the interlocutors exchange and evaluate reasons (including counter-reasons) in order to acquire some epistemic good, such as knowledge (cf. Schwartz and Baker, 2017). Here I'll focus on this phenomenon, which I'll present below (§2), but let me make clear that other researchers have used different terms to refer to it, including 'collaborative reasoning' and 'deliberative argumentation' (cf. Asterhan and Schwarz, 2016; Chinn et al., 2001; Felton et al., 2019). The term choice is to deliberately distance myself from possible wider theoretical connotations that the other ones might be associated with.
} 
are both universal and cut across different domains. Here I focus on a particular instance of this division of cognitive labour: namely, interpersonal argumentative deliberation, where, roughly, the interlocutors exchange and evaluate reasons in order to acquire some epistemic good (below I'll introduce the phenomenon more precisely and use the less cumbersome 'argumentative deliberation' to refer to it). In this natural and ubiquitous sort of deliberation (Mercier and Sperber, 2017), the interlocutors are jointly tackling the same epistemic task and, as we'll see, epistemic benefits regarding the eradication of errors via, partly, the counteraction of cognitive shortcomings are gained. ${ }^{3}$

Having said that, argumentative deliberation can only increase our epistemic performance if certain conditions hold. As we'll see, to reap its epistemic benefits, the argumentative deliberators seem to need to instantiate a certain cognitive diversity and intellectual character. More specifically, regarding the latter, the deliberators, as we'll see, seem to need to be intellectually humble and autonomous. So, given that argumentative deliberation helps us, qua collective, overcome our individual cognitive shortcomings and it can do so in different domains and about different issues, the intellectual virtues of humility and autonomy seem to have a significant impact on our personal and political lives. So, assuming some plausible aims of education (such as enabling personal flourishing and forming competent citizens), it seems that the educational system should foster intellectual humility and autonomy. Moreover, if this is so, an important question is whether these virtues can be developed in the classroom and so the feasibility of such development is explored.

The paper then proceeds as follows. In $\$ 2$, I introduce the phenomenon of argumentative deliberation and argue that it can increase our epistemic performance by eradicating errors and neutralising biases. In $\$ 3$, I argue that these epistemic benefits can be reached only if certain cognitive diversity and intellectual character are to be found among the argumentative deliberators. In $\$ 4$, given some plausible aims of the educational system, I put forward some reasons for it to foster this intellectual character. In $\$ 5$, I offer some pedagogical strategies for the development of such character. In $\$ 6$, I offer some brief concluding remarks that encourage more empirical work to make progress within the incipient field of intellectual virtue development and education.

\footnotetext{
3 As it will become clear in $\S \S 2-3$, I am concerned only with some individual- and group-level cognitive shortcomings (such as the confirmation bias and group polarisation). I take it that many factors can in principle play a role in beliefs' causal history, from sub-personal and personal factors to social and situational ones, and here I suggest that some sub-personal and social ones can be counteracted by certain character traits, among other things.
} 


\section{Argumentative Deliberation and Epistemic Performance}

Argumentative deliberation is the process by which individuals weight the merits of competing reasons in discussion together. In particular, the individuals, conversing together, jointly explore the plausibility of some claim, typically each bringing a slightly different perspective to bear. The individuals are meant to defend those perspectives, which are challenged by their interlocutors. These challenges cannot be ignored and reasons (some of which are tailored to specific objections raised) are evaluated in this exchange. For example, one party may advance a reason $\mathrm{R}_{1}$ in favour of some claim and another one may respond by introducing a counter-reason or defeater $\mathrm{D}$ that speaks against the claim; then the first one may introduce a defeater of the defeater $\mathrm{DD}$ or concede $\mathrm{R}_{1}$ has been defeated-or weakened to certain extent-and perhaps introduce some new reason $R_{2}$ and so on, and eventually they weight the reasons for and against to see how strong is the case for the claim (see also Chambers, 2003, p.309). In this sort of deliberation, each party attempts to rationally persuade the other parties by them seeing the quality of the reasons (not by, say, manipulating or bargaining with them). So argumentative deliberation is here to be understood as the interpersonal practice that involves the production and evaluation of epistemic reasons in favour and against some claim and its consequent possible revision (Andrews, 2010; Asterhan and Schwarz, 2016; Bova, 2017; Felton et al., 2019; Govier, 2010; Leitão, 2000; Schwartz and Baker, 2017).

So, why can this argumentative deliberation be epistemically better than reflectively considering some claim on one's own? One reason has to do with the dispersal of knowledge. Different people, as one would expect (given the hyper-specialised society we live in), often bring to the discussion different knowledge. This additional flow of information can bring to the discussion new reasons and defeaters and so increase the chance that erroneous views be corrected (Fearon, 1998). But people can be diverse in other ways too. For example, people can also vary with respect to the cognitive skills they exploit to target some issue (or how they use them). And this too can serve the aim of correcting errors. For example, by pooling our limited and fallible cognitive abilities, we increase the chance to pick out errors either because you think (on your own, given your abilities), say, some possibility that I wouldn't have thought (and vice versa) or because some possibility is put forward that is the brainchild of our abilities and interaction (and neither of us could have thought of it on our own-cf. Fearon, 1998). So, as one would expect given the above, when it is demonstrable the correctness of some claim, although it is difficult to reach it, diverse groups are much more likely to identify the truth than individuals on their own (Moshman and Geil, 1998; Larson, 2010). 
Another reason has to do with neutralising certain cognitive shortcomings. To appreciate this, let me first introduce two pervasive forms of faulty thinking that have been identified. The confirmation bias is the long-recognised phenomenon regarding the tendency to seek and collect reasons that support one's beliefs and ignore those that contradicts them, for which there is ample evidence that permeates the population (Mercier, 2017; Nickerson, 1998; Scherer et al., 2013). Specifically, it is the natural and pervasive tendency to find reasons for one's beliefs and against beliefs one opposes and it doesn't apply to the evaluation of reasons (Mercier, 2017).

However, argumentative deliberation also involves evaluating reasons. And when it comes to evaluating reasons and arguments that one opposes, we scrutinise them for longer and subject them to much more extensive refutational analysis than those that agree with our prior beliefs (Edwards and Smith, 1996; Evans, 2017; Lodge and Taber, 2013). Given this disconfirmation bias, we are more inclined to detect errors in reasoning for a conclusion with which, to begin with, we disagree. Relatedly, research by Emily Pronin and colleagues on our bias blind spot shows that we are better at detecting cognitive biases in others than in ourselves (e.g. Pronin et al., 2004). All of this means that one is a more rigorous evaluator of opposing views (leaving aside the fact that, given the confirmation bias, we are unlikely to find defeaters for one's view). Nevertheless, none of this means that one cannot recognise and concede to a good reason or argument against one's view. In fact, even when people are confident about some view, they can change it if the reasons suggest it (Fishkin, 2018; Hess and McAvoy, 2015; Mercier and Sperber, 2017). ${ }^{4}$ But, of course, it does suggest that one probably cannot alone come up with some such reason against one's view and so

\footnotetext{
4 See also Kuklinski et al. (2000), Lynch (2019, pp.147-9) and Redlawsk et al. (2010, p.590), for the possibility of change even when holding extreme views very confidently. Having said that, there is the well-known phenomenon of belief perseverance (e.g. Ross et al., 1975) that seems to speak against our capacity to change our mind in response to reasons. In fact, we don't only seem to display belief perseverance when facing disconfirming information, we also seem to suffer a "backfire effect" (Nyhan and Reifler, 2010): we increase our confidence on our belief when facing such disconfirming information (that is, updating our confidence in the wrong direction). However, the settings for the experiments where these phenomena are meant to show up are not deliberative; hence the studied phenomena aren't incompatible with our changing our mind in response to reasons in argumentative deliberation. Moreover, a recent meta-analysis regarding the psychological efficacy of disconfirming information suggests that the debunking effect is more effective when people are provided with new detailed reasons, which is likely to be the case in argumentative deliberation with relevantly diverse individuals (as we'll see below), that enables them to adjust the mental model justifying their beliefs (Chan et al., 2017). Furthermore, as our anxiety increases because more counterevidence is confronted, we pay more attention to the evidence and start making the right adjustments to our beliefs (Redlawsk et al., 2010). So it isn't surprising that the "backfire effect" has failed to be replicated (Wood and Porter, 2019) and, given the above, one can reasonably expect someone to change her mind if the reasons of the argumentative deliberation suggest it. Also, as we'll see below, a certain intellectual character is required for successful argumentative deliberation and such character fosters a more adequate use of such disconfirming information (see also Chan et al., 2017, p.14; Myers, 2019, p.93).
} 
argumentative deliberation can again prove itself epistemically useful given that it allows for the interaction of individuals with disagreeing views.

Given this interaction, both the confirmation and disconfirmation biases become part of an elegant and useful way of dividing cognitive labour (for more on this and a plausible evolutionary story supporting it, see Mercier and Sperber 2017). On the one hand, the confirmation bias makes each individual come up with a (relevantly strong) case in favour of their own views. And although one doesn't search for reasons against one's view, the other, who disagrees with one, does. So each presents the best case for and against some view. On the other hand, the disconfirmation bias makes each individual a rigorous judge of the other's reasons. Although one doesn't scrutinise one's reasons assiduously, the other, who disagrees with one, does: each one controls the quality of the reasons provided by the other. So, given that we can recognise and concede to a better reason, the less error-prone case-given the available evidence-is likely to prevail (given that, as seen, we can expect this argumentative process to increase our chances to detect errors and neutralise biases, we can expect it to increase the plausibility of the resulting view).

This interactive process of production and evaluation of reasons involves a division of cognitive labour that renders these natural, and otherwise epistemically harmful, tendencies into useful features of the mind. In other words, in argumentative deliberation, we aren't merely neutralising these systematic tendencies that prevent us from deliberating responsibly if done individually (since they decrease our chances of finding reasons against one's views and recognising bad reasons for it), but also taking advantage of them (by exploiting each other's tendencies) in order to achieve a more plausible position. We can get rid of these cognitive biases by thinking together in a critically engaged manner and so, in so far as argumentative deliberation is pursued cooperatively, increase our epistemic performance. ${ }^{5}$

\footnotetext{
5 Of course, I have not argued that argumentative deliberation can neutralise all relevant biases, and nor is it my intention to suggest so. I have only argued that two ubiquitous biases, the confirmation and disconfirmation biases, which pervasively affect individuals in their inquiries, can be neutralised. Having said that, although argumentative deliberation can help us improve our epistemic performance with regard to certain biases that affect us at the individual level, it might introduce new ones that affects us at the group level. Deliberation is a group-based phenomenon and below we'll be concerned with a very common problem facing groups: group polarisation. In this case, as we'll see, groups of likeminded individuals polarise and so the relevant heterogeneity is to be encouraged in order to avoid the polarisation. But, of course, there are other issues to be concerned about, such as the well-known group bias (Hewstone et al., 2002). Overcoming (individual and group-level) biases isn't easy for us, particularly when left to our own devices. It is, moreover, very likely that no one single strategy will be effective to overcome them. The strategy here employed to deal with the confirmation and disconfirmation biases is to exploit group interaction in certain conditions Igroup members should be relevantly diverse and possess a certain intellectual character; see next section). In other words, argumentative deliberation doesn't cancel cognitive biases merely by assembling individuals into a group. Moreover, argumentative deliberation, by requiring people to justify their public decisions, can interrupt some of our usual cognitive patterns. In fact, it encourages people to "more careful processing of information
} 


\section{Cognitive Diversity and Intellectual Virtues}

So collective deliberation can lead to epistemically good outcomes but whether it does so depends on certain conditions holding. We have already noticed the role that diversity of knowledge and cognitive skills play in promoting these benefits. But notice too that diversity of opinion is required if people are to search for different reasons and to assiduously evaluate opposing views. Indeed, argumentative deliberation seems to be epistemically harmful in the absence of this diversity. After all, homogenous groups may fail to produce reasons against their shared beliefs and members may provide each other with additional reasons supporting them. Group homogeneity can promote group polarisation: that is, the members of the group end up with more extreme beliefs than they had prior to deliberation (Isenberg, 1986). This polarisation can result, as just shown, from the sharing of confirmatory information (Sunstein, 2006, pp.65-7). But another process that can bring about group polarisation is social comparison: in this case, the polarisation results from in-group comparisons. Even if the group doesn't share information, its members attempt to maintain their reputation and self-conception by emphasising the attitudes they perceive to be normative within the group (Sunstein, 2006, pp.67-9). But this again is likely to happen only in a group of likeminded people, so the suggested group heterogeneity can also remedy group polarisation due to social comparison. ${ }^{6}$

So epistemically beneficial cognitive diversity within the deliberative group comes in different ways (as diversity of opinion, of knowledge, and of skills), but more is required of the deliberators if argumentative deliberation is to increase epistemic performance. In particular, the individuals in argumentative deliberation need to possess a certain intellectual character. For example, they need to be willing to engage in argumentative deliberation although their views seem right to them and to

and reduces cognitive biases le.g., stereotyping, group bias, primacy effects, anchoring effects in probability judgements, fundamental attribution errors [and framing effects])" (Chong, 2013, pp.114, 118; who provides support for these claims). Nevertheless, even if certain individual and group-level biases can be overcome with the right kind of deliberation (via both the interaction of certain individuals, as specified below, and the nudging it promotes), argumentative deliberation isn't here presented as the solution to all our cognitive shortcomings and, importantly, it isn't incompatible with other efforts to overcome them. In fact, some other strategies (not prompted by argumentative deliberation) are also likely to be required to overcome other biases (for a distinction between strategies, see Hertwig \& Grüne-Yanoff, 2017). This more comprehensive inquiry into all the different measures to be adopted to overcome all possible shortcomings is beyond the scope of the present paper.

6 At this point, one might complain that even if a group is heterogenous, minorities within it might self-silence themselves (for fear to be ridiculed or some other social punishment-Sunstein, 2006, p.68), but a group norm that welcomes dissent can encourage the minority to contribute (Paluck and Green, 2009- see fn.5, for the compatibility of strategies). Of course, whether someone is then heard when speaking is another issue; people might not listen to others because of differences in social identity, gender, etc., but, as we'll see, intellectual humility is in part required to promote such listening. Anyhow, the evidence in favour of consistent and significant group polarisation in deliberation is only found in homogenous groups (e.g., Levendusky et al., 2016; Luskin et al., 2014). 
revise their views in response to the reasons brought forward by others (otherwise, argumentative deliberation, with its back-and-forth of reasons, would just be a futile exercise). So, to be able to exploit this division of cognitive labour, one needs to possess the intellectual virtue of humility. ${ }^{7}$ This is so if intellectual humility is understood as the virtuous mean between epistemic arrogance and self-deprecation: neither does the intellectually humble person overestimate her knowledge and epistemic capacities, nor does she underestimate them (cf. Roberts and Wood 2007, pp.236ff., who seem to neglect the self-deprecation extreme; but it seems that one can be too humble: not only the deficit but also the excess of humility, where one under-rates one's epistemic self, seems vicious). In particular, the intellectual virtue of humility reduces epistemic arrogance (without underappreciation of one's knowledge and epistemic capacities) by promoting a doubting attitude owing to the recognition of our fallibility (due to, say, biases and prejudices) and our knowledge limitation (due to, say, our finite cognitive power and time). This dimension of intellectual humility makes clear how it can render one open to engage in argumentative deliberation. Moreover, this virtue also seems to involve a disposition to change and make up one's mind even due to others' opinions. After all, it seems that if the above recognition doesn't impact on one's opinions then it is difficult to think of it as such. This dimension of intellectual humility makes clear how it can help one depend epistemically on others in certain circumstances. Given the above, intellectual humility can be understood as some sort of confidence management of one's beliefs and epistemic capacities, which allows us to make epistemically proper use of others (cf. Baehr, 2015; Church and Samuelson, 2017; Kidd, 2016; Whitcomb et al., 2017).

However, to benefit from argumentative deliberation not only is the individual required to be intellectually humble but also intellectually autonomous. This is so if intellectual autonomy is understood as the virtue that reduces sheer epistemic dependence on others by promoting a willingness and ability to think critically for oneself in judging views, without capitulating to hyper-individualism (cf. Baehr, 2015; Grasswick, 2019; Roberts and Wood, 2007, pp.257ff.; Siegel, 2017, pp.89ff.). In other words, one has the dispositions and attitudes to self-govern intellectually, which include, among other things, seeking reasons, demanding reasons, and assess-

\footnotetext{
7 A virtue is understood as consisting of attitudes and dispositions of the agent which "perfect" a natural human faculty or correct for proneness to dysfunction and error in certain situations (Roberts and Wood, 2007, p.59). An intellectual virtue consists, roughly, of attitudes and dispositions for good and productive thinking (Ritchhart, 2002, pp.18-31). Intellectual virtues are typically acquired although the virtuous agent needn't be responsible for possessing them (Battaly, 2019).
} 
ing for oneself beliefs, reasons and sources of them. ${ }^{8}$ So, given that, as mentioned, each party in argumentative deliberation controls the quality of the reasons provided by the opposing party and tailors their reasons to the objections raised, this virtue's dispositions and attitudes to critically assess also play a central role in such deliberation. So both intellectual virtues, humility and autonomy, are required for us to take proper advantage of this division of labour. It is important, however, to note that intellectual autonomy isn't in tension with intellectual humility, contrary to what one might think if autonomy is taken to entail a Cartesian-like ideal of autonomy (fn.1) and humility to entail openness to epistemic dependence. To see that they aren't incompatible, note first that the above virtue of intellectual autonomy isn't a matter of sheer epistemic independence. Indeed, such Cartesian hyper-individualism is one of the vicious extremes in-between which is the virtuous mean of intellectual autonomy (the other extreme being sheer epistemic dependence). So being intellectually humble (and so being open to epistemic dependence) isn't in tension with being intellectually autonomous. Indeed, intellectual autonomy concerns what one does with one's, as seen, inevitable epistemic dependence on others: put differently, it involves some sort of dependence management. Although the Cartesian ideal of autonomy might be an apt ideal for a superior being, like Descartes' God, it isn't an ideal for the kind of being we actually are (Fricker, 2006). Given our limited powers, we cannot know for ourselves everything we want and need to know. More precisely, given our cognitive, spatial and temporal limitations and that such a dependence rewards us with epistemic riches, a good human epistemic subject is to epistemically rely on others. But one shouldn't do this blindly, and intellectual autonomy, qua dependence-management, requires that one be able to discriminate between the epistemically good and bad beliefs and reasons that others offer us. So not only is intellectual autonomy not in tension with intellectual humility (the former involves the management of our epistemic dependence and the latter the management of our epistemic confidence so to be open to such epistemic dependence) but it also helps us avoid gullibility (see also Dunning, 2019, p.230; Myers, 2019, p.93).

\section{The Significance of Educating for Intellectual Humility and Autonomy}

It is important to make clear that the epistemic benefits of argumentative deliberation aren't limited to the acquisition of certain kinds of belief. In all domains of life (in different contexts and regarding different issues), we can exploit argumentative

8 Note the virtue not only requires the critical skills to intellectually self-govern but also the willingness to exploit them (Baehr, 2019). 
deliberation to increase our epistemic performance in the acquisition of beliefs. Moreover, the significance of argumentative deliberation is clear when considering both individual and collective aspects of our lives. Regarding the former, one normally wants to believe what is true and avoid believing what is false. After all, given that one's actions are based in what one believes to be the case, if those beliefs are actually false, it is more likely that one will act in ways that contravene one's intentions and undermine one's aims (Dretske, 1989; Kornblith, 1993). So, given that the success of one's actions depends on the truth of one's beliefs and the fact that argumentative deliberation eliminates errors and biases, such deliberation can prove useful when considering issues that matter to one.

Moreover, and perhaps more importantly, we want to be governed by institutions that can recognise good reasons and reject bad ones. In fact, democracies are the political manifestations of our aspiration to be guided by our better reasons. A government can commit grave forms of injustice (the sort of injustices that can affect many people and in a systematic way) and we don't want to make these high-cost mistakes. Although it is common to think of (representative) democracy in terms of regular and fair elections, it is much more than that. It involves a great variety of collective activities. For instance, voting is preceded by electoral campaigns where candidates, journalists, experts and citizens interact in the attempt to exchange reasons (Jacobs et al., 2009). And after voting, citizens, experts and journalists are to hold elected authorities accountable for their decisions. Indeed, it is a basic commitment of modern democracy that people can participate in acts of protest, resistance and dissent and many of the freedoms protected by it, such as the freedom of expression, of press and of association, are directly linked to that (Pettit, 2013; Whelan, 2019). Dissenting citizens, even if they are a minority, can deliberate and critique a given political decision and bring about social change, which shows our social aspiration for our collective lives to be guided by our better reasons: "by the unforced force of the better argument" (Habermas, 1996, p.306). So a pivotal component of democracy is the attempt to argue with each other about what we collectively should do (Bohman, 1996; Fishkin, 2018; Gutmann and Thompson, 2004; Landemore, 2013). Democracy is collective self-government where we attempt to collectively determine via public argumentative deliberation the policies and actions that enjoy the support of our better reasons. In fact, one can take (as it has been done) this argumentative deliberation to be the source of legitimacy of political decisions (Cohen, 1989; Estlund, 2008; Manin, 1987; Peter, 2009). So it is of the outmost importance that democratic citizens can engage properly in such deliberation. 
Given that argumentative deliberation can and ought to have a central role in our everyday personal and political lives in order to better conduct them, one would expect that learning to adequately engage in it would be a priority of the educational system. In fact, if we assume, as it is often assumed, that two key aims of education are to enable personal flourishing and form competent democratic citizens (Brighouse, 2009; Macleod and Tappolet, 2019; Nussbaum, 1997), the development of the cognitive capabilities (e.g. skills, attitudes and the like) required to adequately engage in such deliberation turns out to be a crucial goal of the system to enable the satisfaction of its aims. Furthermore, and independently of those aims, given that the epistemic aim of education isn't merely to transmit knowledge or some other epistemic good to people but to provide them with the cognitive capabilities to be able to acquire those goods for themselves and with others (Robertson, 2009; Pritchard, 2014), the educational system should then foster the development of the relevant cognitive capabilities for proper argumentative deliberation. As seen, this propriety requires the deliberators to be intellectually humble and autonomous. So, given the aforementioned plausible educational aims, one important goal of the educational system is the development of such intellectual character. ${ }^{9}$

I take it that the above gives us a good enough prima facie case for the educational commitment to develop the intellectual virtues of humility and autonomy in people. Of course, justifications for the development of intellectual virtues generally have been offered in the literature (Baehr, 2014; Battaly, 2016; Pritchard, 2014), but here I am only concerned with intellectual humility and autonomy and the justification offered only concerns these two virtues. Given the role they play in successful argumentative deliberation and the role this deliberation plays in satisfying different plausible aims of education, these virtues ought to be fostered in the classroom. At this point, someone might rightly point out that we have also made a case for the need for cognitive diversity in order for us to engage in proper argumentative deliberation and so one might wrongly think that such diversity should also be fostered in the classroom. The relevant diversity is normally found in society. First, as mentioned above, knowledge is typically distributed among individuals and so will different cognitive skills given the division of professional labour, among other things. Moreover, it is also a matter

\footnotetext{
9 Of course, other educational aims are often suggested, such as the ability to contribute to economic life, the capacity for cooperation, and personal autonomy (Brighouse, 2009). It should be clear how intellectual autonomy contributes to personal autonomy given that, as seen, it's required to better regulate our reasons and beliefs including those regarding how to live one's own life (see also Winch, 2006). Further, it should also be clear how intellectual humility contributes to the capacity for cooperation: at least, regarding epistemic cooperation (which is, as seen, an ubiquitous and needed aspect of our lives); and it has been argued that it contributes to economic life too (Hess and Ludwig, 2017). Finally, note that there is some evidence that suggests that intellectual humility might bring physical and mental health gains (Toussaint and Webb, 2017).
} 
of fact that people have different opinions about different matters, partly because of diverse spatio-temporal opportunities and demographics. So the relevant diversity is typically out there and, in an inclusive educational system, one can expect some of that diversity to be found in the classroom too (Enslin and Hedge, 2010).

Having said that, normally the relevant character isn't naturally found out there. Of course, we can find some people with such character but usually they have been trained to develop it. For example, one can expect to find this character in professional scientists. After all, the ethos of science seems to require it (Merton, 1973). On the one hand, one norm behind this ethos, which guides the scientific community, is "organized skepticism," which recommends "the detached scrutiny of beliefs in terms of empirical and logical criteria" (1973, p.277) and clearly requires intellectual autonomy. And so too "disinterestedness" given that "scientific research is to be under the exacting scrutiny of fellow experts" (1973, p.276). On the other hand, intellectual humility, as the recognition of one's personal limitations, is also required by the ethos of science (1973, p.303). So a typical, well-trained, professional scientist will possess, to a bigger or lesser degree, both virtues (Kidd, 2011; McIntyre, 2019; Myers, 2019). But science is a very particular institution and most other formal institutions, including the legal and political ones, aren't too preoccupied with the willingness to embrace that particular mindset by their specific communities. Indeed, most people in society aren't likely to go through some training to develop the relevant dispositions and attitudes associated with intellectual humility and autonomy in their given professional instruction. ${ }^{10}$ So to ensure that people develop these virtues, the educational system's compulsory branch should make the efforts to instantiate pedagogies that promote this development.

In the next section, I'll point to some formal education strategies and practices to contribute to the nurturing of these two virtues in the classroom so as to give a sense of the feasibility of the task. But educating for virtues requires a coordinated vision of pedagogy, the curriculum, the evaluation of students and teachers, the ethos of schooling and teacher education, and such comprehensive view is certainly beyond the scope of this paper. So the pedagogical strategies and practices here suggested are not by themselves sufficient to produce these virtues. Moreover, formal education is, ideally, to be complemented informally outside the classroom: minimally, intellectual

\footnotetext{
10 Worse still, studies suggest that in universities, where much professional instructions happens, students tend to be intellectually arrogant; see DeWall, 2017, p.235. Indeed, Kidd (2016, pp.66-70) offers some reasons as to why much of modern education might militate against the development of virtues and, particularly, intellectual humility. As Battaly (2016, p.163) says, "universities have not yet systematically addressed whether and how to help students develop [intellectual] character traits."
} 
character education should be a joint enterprise between schools and families (Ryan and Bohlin, 2003; Berkowitz and Bier, 2007). So their fostering should also require a coordinated effort involving a series of actors and practices outside the classroom. Having said that, next I merely give some cues as to how some classroom strategies and practices can contribute to this fostering.

\section{The Feasibility of Educating for Intellectual Humility and Autonomy}

If intellectual humility and autonomy ought to be fostered in the educational system, an important question is whether they can be developed. There are different, empirically supported, models of virtue development from moral virtue theory (which has been more extensively studied) that can be extended to intellectual virtues. ${ }^{11}$ These models present alternative routes towards virtue and three such models are the development of (proper, global) virtues from local traits (Russell, 2009; Snow, 2010), from "folk virtues" (Snow, 2018), and as skills development (Annas, 2011; Stichter, 2011). Regarding the first one, it concerns the extension of local traits that one already possesses: say, extending one's local critical disposition in some domain to others to which one isn't already disposed to apply them. ${ }^{12}$ In this case, one doesn't start from scratch but rather from some local trait and, being aware of one's deficit (given what the global virtue requires) as well as being motivated to reach such generalisability, one needs to put the cognitive effort to acquire the relevant general dispositions and attitudes (say, in the case of intellectual autonomy, the above dispositions and attitudes to self-govern intellectually in different domains). Regarding the second model, it exploits the possession of virtue-relevant goals to develop automatic habits of virtuous behaviour. In this case, one doesn't start from scratch either but rather from some relevant desire (say, to be intellectually humble) and, being aware

\footnotetext{
11 Indeed, Zagzebski (1996, p.150) has claimed that the stages of learning the intellectual virtues are "exactly parallel to the stages of learning the moral virtues." Interestingly (but perhaps not surprisingly) enough, the strategies offered below echo much of Aristotle's account of moral virtue development, as opposed to intellectual virtue development (e.g. Aristotle, 1987, 1103a15-b6).

12 This model is born of concerns the situationist critique planted. Particularly, situationist research in social psychology suggests that (often trivial) environmental variables can have greater explanatory power than character traits. And although it is true that there is good evidence that sometimes situations are quite powerful (Benjamin and Simpson, 2009), the stronger claim that also appears to have widespread acceptance is that personality and individual differences have little to no effect once the impact of the situation is accounted for (Jost and Kruglanski, 2002). Indeed, Harman (2000) argues against the existence of character traits and Doris (2002), more moderately, argues that only "narrow" (i.e. local), as opposed to global, traits can be empirically supported. And, as one would expect, the debate has recently moved to the intellectual domain (Fairweather and Alfano 2017). This certainly overlooks scholarship that has produced contrary evidence. In fact, the typical effect size for a situational effect on conduct is about the same as the typical effect size for personality characteristics (Fleeson, 2004; Fleeson and Noftle, 2008; Funder, 2006). Indeed, some virtue theorists have argued that the situation-person debate is misguided and that educators should make use of situational factors to help people develop the virtues (Athanassoulis, 2016; Battaly, 2014).
} 
of what the object of one's desire entails (say, a disposition to change and make up one's mind even due to others' opinions), one, via practice (as research on automaticity suggests), acquires the relevant dispositions and attitudes. The third model doesn't assume that either some local trait or virtue-relevant goal is already possessed by the subject and suggests, based on skill development research, that by following some rules, one can develop the relevant habits: say, one might initially start with the rough rule of constantly questioning one's intellectual capacity to then, as the subject gains more experience, start introducing more fine-grained (and context-sensitive) ones, as intellectual humility requires. In this case, just like in the previous ones, one needs to be appropriately motivated, to understand what one is striving for, and to practice as required. Moreover, in all three cases, some monitoring as to whether one is progressing or not in the acquisition of the virtue is required. But the third model, because no previous virtue-relevant motivation or local trait is assumed, present us with the most challenging picture. So below I present different educational strategies and practices, which are empirically supported, that address the four aforementioned components: having the right conception of the target virtue, the motivation to aspire to it, the opportunities to practice and the opportunities to monitor one's progress.

Given the need for the right conception of the target virtue, explicit instruction about the intellectual virtues is essential, as it is often acknowledged (Baehr, 2015; Battaly, 2016; Zagzebski, 1996). After all, it's important to know what one is striving for. Moreover, by teaching students what the virtues (say, intellectual humility) and its corresponding vices (say, intellectual arrogance and self-deprecation) are, they can have greater awareness of opportunities to practice the virtues, as it has been argued in the educational literature (Ritchhart, 2002, pp.48, 75, 129-38). Also, this instruction can be exploited to point out the importance of virtues (say, for a democratic society and personal flourishing) and so the teacher can motivate the practice of the students (Ritchhart, 2002, p.48). Finally, such explicit teaching, by providing a shared conceptual framework, can give the teachers and students a common language for successful feedback, which is important not only for the progress' monitoring that it allows but also, in the case of positive feedback, for reinforcement. As it has been convincingly argued in the psychological literature, (immediate) reward is likely to play an essential role in developing a certain automaticity in triggering dispositions (Wood, 2019).

Exposure to exemplars is also often acknowledged as an important pedagogical strategy given that it can serve to model behaviour on the exemplars (Baehr, 2015; Battaly, 2016; Zagzebski, 1996). This modelling is very important for learning: as Ritchhart et al. (2011, p.29) say, "[when] we learn anything, we rely on models. We 
attend to what and how others are doing things, and we imitate them." So teachers should model aspects of intellectual humility and autonomy when explaining material to their students and responding to students' comments and questions, among other things (Ritchhart, 2002, pp.161-4, 2015, pp.135-7). But it doesn't follow that to have a significant impact, a teacher needs to be perfectly virtuous and, in fact, owing to one's intellectual limitations can be an opportunity to practice intellectual humility (Roberts, 2016, p.197). Moreover, exposure to exemplars can serve to inspire motivation and to engender emotions that support virtuous intellectual conduct (Battaly, 2014, p.195; Ritchhart, 2002, p.166).

Further, to pursue some intellectual conduct, it's important that one habituates in oneself a sufficiently strong attitude in favour of such conduct and (repetitive) practice is crucial to elicit a process of habituation, as it has been argued in the educational and psychological literature (Ritchhart, 2002; Wood, 2019). So virtue-specific activities can be practiced and improved upon so to develop a disposition to act in a virtuous way, and this "skill dimension" of an intellectual virtue is also often acknowledged (Baehr, 2015; Battaly, 2016; Zagzebski, 1996). There are many different ways to build opportunities to practice (in group activities, individual assignments and tests, among other things), but here I am just going to mention some, which have been shown to be successful in producing certain effects (to be specified below), to give you a sense of the kind of things that can be done. First, exploiting Ann Brown's (1997) widely-tested Fostering Communities of Learners approach, one can divide the class into groups, so for each group to specialise on some issue, and then regroup the students by getting one student from each previous group to solve some problem. In this case, expertise is deliberately distributed and so collaboration is necessary to succeed. This interdependence helps the students develop attitudes to work well with others and so to avoid one of the vicious extremes related to intellectual autonomy: hyper-individualism (cf. Roberts, 2016, p.197-8). More generally, the purpose of these "peer education" strategies that focus on the importance of teamwork in learning can be thought of as creating better users of the divisions of epistemic and cognitive labour.

Second, exploiting Diana Hess and Paula McAvoy's (2015) Best Practice Discussion approach, one can make students spend more than $20 \%$ of the classes' time discussing controversial issues among themselves. This kind of group activity requires students to prepare in advanced and, of course, there are high levels of student participation and significant student-to-student talk. Their empirical research shows that Best Practice Discussion students are significantly more likely to be willing to listen to and engage with those who disagree (and consider this important) 
and to engage in efficient discussion (which also clarifies their own views), among other things, compared to students who engage in student-to-teacher discussion of controversial issues more than $20 \%$ of the time and don't prepare in advance or students whose classes' dominant pedagogical strategy was teacher lecture (of very high quality). So this practice helps students to foster, among other things, the dimension of intellectual humility that relates to the openness to engage in argumentative deliberation and particularly to the disposition to make up one's mind even due to others' opinions.

Third, exploiting Ron Ritchhart's $(2002,2015)$ Thinking Routines approach, one can set thinking scaffolds that are part of the infrastructure of the classroom to facilitate the practice of intellectual humility and autonomy. These routines typically have few steps that can be easily remembered and get repeatedly used in different contexts both publicly and privately to produce global patterns of conduct (2002, p.92, 2015, p.195). Two relevant and well-tested examples of them are "What Makes You Say That?" and "Circle of Viewpoints" (Ritchhart et al., 2011, ch.6). The former can be a private routine that needn't be set up as a class activity, which provides an opportunity to practice intellectual autonomy as it helps students identify the basis of their beliefs by asking them to reflect on and articulate their underlying reasoning. The overall goal is to encourage students to form the disposition to critically assess their own reasons for belief. But asking students why they have a particular belief invites not only reflection on the evidential reasons they might have but also on the possible non-rational factors that might be behind their beliefs. So this routine promotes a habit of careful and thorough assessment on the evidential reasons and other causes of one's beliefs. "Circle of Viewpoints" is a public routine that requires a set-up of group activity, which aims to identify and consider different point of views of the students on some matter and so its purpose is to "[create] a greater awareness of how others may be thinking and feeling and [reinforce] that people can and do think differently about the same things" (Ritchhart et al., 2011, p.171). This routine provides an opportunity to practice intellectual humility given that, by the different perspectives which are likely to be put forward (in an inclusive classroom), they can learn that their own perspective is often quite limited and incomplete.

Finally, let me briefly point out that teachers must not only explicitly teach about the virtues, model virtuous conducts and create opportunities for practicing those conducts, they must also evaluate the conduct of the students. This is important because allows teachers to monitor the students' progress and so react to possible deficits and obstacles in the formation of intellectual humility and autonomy. Furthermore, the teacher's feedback allows students to monitor their own progress 
and, to the extent that there is progress, it can elicit some intrinsic motivation to cultivate the virtues and, to the extent that some deficit is pointed out, it can trigger its correction, as the educational literature suggests (Andrews, 2010, pp.4-5, 30, 119; Ritchhart, 2002, p.166). Also, positive feedback importantly provides an extrinsic reward that is key for their formation (Wood, 2019, pp.115-20). Of course, (summative and formative) assessments need to be accompanied by their corresponding guidelines with explicit and detailed ground rules so to allow the students and teacher to operate from the same assumptions and so effectively evaluate the progress (Andrews, 2010, p.4). And, although there is much work related to the assessment of the critical thinking aspect of intellectual autonomy (which is sometimes assessed in assignments, say, when students are asked to articulate and defend a thesis), the same cannot be said about the assessment of the willingness to exploit such thinking and of intellectual humility generally.

So, assuming this battery of pedagogical tools, strategies and practices gives you enough of a sense of the sort of thing that can be done to foster intellectual humility and autonomy and so to suggest that such virtues can be cultivated, it isn't senseless to require their teaching as argued above. Having said that, it's clear that much more work is still required to perfect and complete such teaching and to show that it promotes the development of these virtues.

\section{Conclusion}

We have seen that we are epistemically interdependent and, in particular, that argumentatively deliberating with others can increase our epistemic performance by eradicating errors and neutralising biases. However, to reap these epistemic benefits, the argumentative deliberators seem to need to instantiate a certain intellectual character; more specifically, to be intellectually humble and autonomous. So, given that argumentative deliberation can have a central role in our everyday personal and political lives in order to better conduct them, one would expect that learning to adequately engage in it would be a priority of the educational system. In fact, if this system aims to enable personal flourishing, to form competent democratic citizens or merely to provide people with the cognitive capabilities to be able to acquire epistemic goods for themselves and with others, there is a good case for the educational commitment to develop the intellectual virtues of humility and autonomy in people. Given this, we have explored the feasibility of such commitment. However, intellectual virtue development and education is still in its infancy and I hope that the reasons provided for the cultivation of intellectual humility and autonomy, regarding 
their enabling role in proper argumentative deliberation and so too in our personal and collective lives, can prompt more empirical work on this area.

\section{Acknowledgements}

An earlier version of this paper was presented at the Congreso Internacional de Argumentación, Aprendizaje y Educación "Argumentar para pensar, aprender y convivir en un mundo complejo" on January 14, 2020. I am grateful for the audience's feedback as well as the valuable comments that I received from two anonymous referees.

This work was supported by the Fondo de Investigación Científico y Tecnológico (FONDECYT, ANID, Chile), 1180886.

\section{Works Cited}

Andrews, Richard. Argumentation in Higher Education: Improving Practice Through Theory and Research. London: Routledge, 2010.

Annas, Julia. Intelligent Virtue. Oxford: OUP, 2011.

Aristotle. A New Aristotle Reader (edited by J.L. Ackrill). Oxford: OUP, 1987.

Asterhan, Christie and Baruch Schwarz. "Argumentation for learning: Well-trodden paths and unexplored territories." Educational Psychologist 51(2) (2016): 164-187.

Athanassoulis, Nafsika. “The Psychology of Virtue Education.” In Masala, A. and Webber J. (eds.), From Personality to Virtue (pp.207-228). Oxford: OUP, 2016.

Baehr, Jason. "Educating for Intellectual Virtues: From Theory to Practice." In Kotzee, B. (ed.), Education and the Growth of Knowledge (pp.106-123). Oxford: Blackwell, 2014.

Baehr, Jason. Cultivating Good Minds: A Philosophical and Practical Guide to Educating for Intellectual Virtues. URL=http://intellectualvirtues.org/why-should-we-educate-for-intellectual-virtues-2-2/, 2015.

Baehr, Jason. "Intellectual Virtues, Critical Thinking and the Aims of Education." In Graham, P. et al. (eds.), Routledge Handbook of Social Epistemology (pp.447-456). London: Routledge, 2019.

Battaly, Heather. "Acquiring Epistemic Virtue: Emotions, Situations and Education." In Fairweather, A. and Flanagan, O. (eds.), Naturalizing Epistemic Virtue (pp.175196). Cambridge: Cambridge University Press, 2014. 
Battaly, Heather. "Responsibilist Virtues in Reliebilist Classrooms." In Baehr, J. (ed.), Intellectual Virtues and Education (pp.163-183). London: Routledge, 2016.

Battaly, Heather. "A Third Kind of Intellectual Virtue: Personalism.” In Battaly, H. (ed.), Routledge Handbook of Virtue Epistemology, (pp.115-126). London: Routledge, 2019.

Benjamin, Ludy and Jeffry A. Simpson. "The Power of the Situation: The Impact of Milgram's Obedience Studies on Personality and Social Psychology". American Psychological Association 64(1) (2009): 12-19.

Berkowitz, Marvin and Melinda Bier. "What Works in Character Education." Journal of Research in Character Education 5(1) (2007): 29-48.

Bohman, James. Public deliberation. Pluralism, complexity and democracy. Massachusetts: MIT Press, 1996.

Bova, Antonio. "The Role of the Teacher in Promoting Argumentative Interactions in the Learning Contexts of Higher Education." In Arcidiacono, F. and Bova, A. (eds.), Interpersonal Argumentation in Educational and Professional Contexts (pp. 75-94). Amsterdam: Springer International Publishing, 2017.

Brighouse, Harry. "Moral and Political Aims of Education." In Siegel, H. (ed.) The Oxford Handbook of Philosophy of Education (pp.35-51). Oxford: OUP, 2009.

Brown, Ann. "Transforming Schools into Transforming schools into communities of thinking and learning about serious matters." American Psychologist 52(4) (1997): 399-413.

Chambers, Simone. "Deliberative Democratic Theory." Annual Review of Political Science 6 (2003): 307-26.

Chan, Man-pui, Christopher Jones, Kathleen Jamieson and Dolores Albarracín. "Debunking: A Meta-Analysis of the Psychological Efficacy of Messages Countering Misinformation." Psychological Science 28(11) (2017): 1531-1546.

Chinn, Clark, Richard Anderson and Martha Waggoner. "Patterns of discourse in two kinds of literature discussion.” Reading Research Quarterly 36(4) (2001): 378-411.

Chong, Dennis. "Degrees of Rationality in Politics." In Huddy, L. et al. (eds.), The Oxford Handbook of Political Psychology (pp.96-129). Oxford: OUP, 2013.

Church, Ian and Peter Samuelson. Intellectual Humility. London: Bloomsbury, 2017.

Cohen, Joshua. "Deliberation and Democratic Legitimacy." In Hamlin, A and Pettit, P. (eds), The Good Polity (pp.21-42). Oxford: Blackwell, 1989. 
De Brasi, L. "Reliability and Social Knowledge-Relevant Responsibility," Transformaçao 38(1) (2015): 187-212.

De Brasi, L. “Knowledge as a Social Kind”, Filosofía Unisinos 18(3) (2017): 130-9.

Descartes, René. The Philosophical Writings of Descartes. Vol. I. (trans. by Cottingham, J. et al.). Cambridge: Cambridge University Press, 1984.

DeWall, Nathan. "Fostering Intellectual Humility in Public Discourse and University Education." In Worthington, E. et al. (eds.) Handbook of Humility (pp.233-245). London: Routledge, 2017.

Doris, John M. Lack of Character: Personality and Moral Behavior. Cambridge: Cambridge University Press, 2002.

Dretske, Fred. “The Need to Know." In Clay, M. and Lehrer, K. (eds.), Knowledge and Skepticism (pp.17-35). Boulder: Westview Press, 1989.

Dunning, David. "Gullible to Ourselves." In Forgas, J. and Baumeister, R. (eds.) The Social Psychology of Gullibility, edited by (pp.217-33). London: Routledge, 2019.

Edwards, Kari and Edward Smith. "A Disconfirmation Bias in the Evaluation of Arguments." Journal of Personality and Social Psychology 71(1) (1996): 5-24.

Enslin, Penny and Nicki Hedge. "Inclusion and Diversity." In Baily, R. et al. (eds.) The Sage Handbook of Philosophy of Education (pp.385-400). London: Sage, 2010.

Estlund, David. Democratic Authority. New Haven: Princeton University Press, 2008.

Evans, Jonathan. "Belief Bias in Deductive Reasoning." In Pohl, R. (ed.), Cognitive Illusions, (pp.165-181). London: Routledge, 2017.

Fairweather, Abrol and Mark Alfano. Epistemic Situationism. Oxford: OUP, 2017.

Fearon, James. "Deliberation as Discussion.” In Elster, J. (ed.), Deliberative Democracy (pp.44-68). Cambridge: CUP, 1998.

Felton, Mark, Amanda Crowell, Merce Garcia-Mila and Constanza Villarroel. "Capturing deliberative argument: An analytic coding scheme for studying argumentative dialogue and its benefits for learning." Learning, Culture and Social Interaction. Online First. https://doi.org/10.1016/j.lcsi.2019.100350_2019.

Fishkin, James. Democracy When the People are Thinking. Oxford: OUP, 2018.

Fleeson, William. "Moving personality beyond the person-situation debate: The challenge and opportunity of within-person variability". Current Directions in Psychological Science 13 (2004): 83-87. 
Fleeson, Wiliam, and Erik Noftle. "The end of the person-situation debate: An emerging synthesis in the answer to the consistency question." Social and Personality Psychology Compass 2 (2008): 1667-1684.

Fricker, Elizabeth. “Testimony and Epistemic Autonomy." In Lackey, J. and Sosa, E. (eds.), The Epistemology of Testimony (pp.225-250). Oxford: OUP, 2006.

Funder, David C. "Towards a resolution of the personality triad: Persons, situations, and behaviors". Journal of Research in Personality 40 (2006): 21-34.

Goldberg, Sandford. “The Division of Epistemic Labour.” Episteme 8 (2011): 112-125.

Govier, Trudy. A practical study of argument (7th ed.). Belmont: Cengage Learning, 2010.

Grasswick, Heidi. "Epistemic Autonomy in a Social World of Knowing." In Battaly, H. (ed.), The Routledge Handbook of Virtue Epistemology (pp.196-208). London: Routledge. 2019.

Gutmann, Amy and Dennis Thompson. Why Deliberative Democracy? New Haven: Princeton University Press, 2004.

Habermas, Jürgen. Between facts and norms. Contributions to a discourse theory of law and democracy. Massachusetts: MIT Press, 1996.

Harman, Gilbert. “The nonexistence of character traits”. Proceedings of the Aristotelian Society 100(1) (2000): 223-226.

Hertwig, Ralph and Till Grüne-Yanoff. "Nudging and Boosting." Perspectives on Psychological Science 12(6) (2017): 973-986.

Hess, Diana and Paula McAvoy. The Political Classroom: Evidence and Ethics in Democratic Education. London: Routledge, 2015.

Hess, Edward and Katherine Ludwig. Humility is the New Smart: Rethinking Human Excellence in the Smart Machine Age. Oakland: Berret-Koehler Publishers, 2017.

Hewstone, Miles, Mark Rubin, and Hazel Willis. "Intergroup Bias". Annual Review of Psychology 53 (2002): 575-604.

Hume, David. An Enquiry Concerning Human Understanding (3rd edition). Oxford: Clarendon, 1975.

Isenberg, Daniel. “Group Polarization: A critical review and meta-analysis." Journal of Personality and Social Psychology 50 (1986): 1141-51.

Jacobs, Lawrence, Fay Cook and Michael Delli Caprini. Talking together. Public deliberation and political participation in America. Chicago: The University of Chicago Press, 2009. 
Jost, John T. and Arie W. Kruglanski. "The estrangement of social constructionism and experimental social psychology: History of the rift and prospects for reconciliation". Personality and Social Psychology Review 6 (2002): 168-87.

Kidd, Ian. "Pierre Duhem's epistemic claims and the intellectual virtue of humility." Studies in History and Philosophy of Science 42(1) (2011): 185-189.

Kidd, Ian. "Educating for Intellectual Humility." In Baehr, J. (ed.), Intellectual Virtues and Education (pp.54-70). London: Routledge, 2016.

Kornblith, Hilary. “Epistemic Normativity." Synthese 94(3) (1993):357-376.

Kuklinski, James, Paul Quirk, Jennifer Jerit, David Schieder and Robert Rich. "Misinformation and the Currency of Democratic Citizenship." Journal of Politics 62(3) (2000): 790-816.

Landemore, Helene. Democratic Reason: Politics, Collective Intelligence, and the Rule of the Many. New Haven: Princeton University Press, 2013.

Larson, James. In Search of Synergy in Small Group Performance. New York: Psychology Press, 2010.

Leitão, Selma. "The Potential of Argument in Knowledge Building." Human Development, 43(6) (2000): 332-360.

Levendusky, Matthew, James Druckman and Audrey McLain. "How Group Discussions Create Strong Attitudes and Strong Partisans." Research and Politics 3 (2016):1-6.

Lodge, Milton and Charles Taber. The Rationalizing Voter. Cambridge: CUP, 2013.

Luskin, Robert, Ian O'Flynn, James Fishkin and David Russell. "Deliberating Across Deep Divides." Political Studies 62(1) (2014):116-35.

Lynch, Michael. Know-It-All-Society. London: Liveright Publishing, 2019.

Macleod, Colin and Christine Tappolet. Philosophical Perspectives on Moral and Civic Education: Shaping Citizens and Their Schools. London: Routledge, 2019.

Manin, Bernard. “On Legitimacy and Political Deliberation.” Political Theory 15 (1987): 338-368.

McIntyre, Lee. The Scientific Attitude. Massachusetts: MIT Press, 2019.

Mercier, Hugo. "Confirmation bias-myside bias." In Pohl, R. (ed.), Cognitive Illusions (pp.99-114). London: Routledge, 2017. 
Mercier, Hugo and Dan Sperber. The Enigma of Reason. London: Allen Lane, 2017.

Merton, Robert. The Sociology of Science. Chicago: UCP, 1973.

Moshman, David and Molly Geil. "Collaborative Reasoning: Evidence for Collective Rationality." Thinking \& Reasoning 4(3) (1998):231-248.

Myers, David. "Psychological Science Meets a Gullible Post-Truth World." In Forgas, J. and Baumeister, R. (eds.) The Social Psychology of Gullibility (pp.77-100). London: Routledge, 2019.

Nickerson, Raymond. "Confirmation Bias: A ubiquitous phenomena in many guises." Review of General Psychology 2(2) (1998):175-220.

Nussbaum, Martha. Cultivating Humanity. Cambridge: Harvard University Press, 1997.

Nyhan, Brendan and Jason Reifler. "When Corrections Fail." Political Behaviour 32 (2010): 303-330.

Paluck, Elizabeth and Donald Green. "Deference, Dissent and Dispute Resolution." American Political Science Review 103 (2009):622-644.

Peter, Fabienne. Democratic Legitimacy. London: Routledge, 2009.

Pettit, Philip. On the people's terms. Cambridge: Cambridge University Press, 2013.

Pritchard, Duncan. "Epistemic Virtue and the Epistemology of Education." In Kotzee, B. (ed.), Education and the Growth of Knowledge (pp.92-105). Oxford: Blackwell, 2014.

Pritchard, Duncan. "Epistemic Dependence.” Philosophical Perspectives 29 (2015):305-324

Pronin, Emily, Thomas Gilovich and Lee Ross. "Objectivity in the eye of the beholder." Psychological Review 111 (2004): 781-799.

Redlawsk, David, Andrew Civettini and Karen Emmerson. "The Affective Tipping Point: Do Motivated Reasoners Ever “Get It"?” Political Psychology 31(4) (2010):563-593.

Reid, Thomas. Essays on the Active Powers of Man (Ed. by Haakonssen and Harris). Edinburgh: EUP, 2010.

Ritchhart, Ron. Intellectual Character: What It Is, Why It Matters, and How to Get It. San Francisco: Jossey-Bass, 2002.

Ritchhart, Ron. Creating Cultures of Thinking: The Eight Forces We Must Master to Truly Transform Our Schools. San Francisco: Jossey-Bass, 2015. 
Ritchhart, Ron, Mark Church and Karin Morrison. Making Thinking Visible. San Francisco: Jossey-Bass, 2011.

Roberts, Robert. Learning Intellectual Humility. In Baehr, J. (ed.), Intellectual Virtues and Education (pp.184-201). London: Routledge, 2016.

Roberts, Robert and Jay Wood. Intellectual Virtues. Oxford: OUP, 2007.

Robertson, Emily. The Epistemic Aims of Education. In Harvey, S. (ed.), The Oxford Handbook of Philosophy of Education (pp.11-34). Oxford, OUP, 2009.

Ross, Lee, Mark Lepper and Michael Hubbard. "Perseverance in self-perception and social perception." Journal of Personality and Social Psychology 32(5) (1975):880-92.

Russell, Daniel. Practical Intelligence and the Virtues. Oxford: Clarendon, 2009.

Ryan, Kevin and Karen Bohlin. Building Character In Schools: Practical Ways to Bring Moral Instruction to Life. San Francisco: Jossey-Bass, 2003.

Toussaint, Loren and John Webb. "The Humble Mind and Body: A theoretical model and review of evidence linking humility to health and well-being." In Worthington, E. et al. (eds.) Handbook of Humility (pp. 178-191). London, Routledge, 2017.

Townley, Cynthia. A Defense of Ignorance. Lanham: Lexington, 2011.

Scherer, Aaron, Paul Windschitl and Andrew Smith. "Hope to be Right: Biased Information Seeking Following Arbitrary and Informed Predictions." Journal of Experimental Social Psychology 49 (2013):106-112.

Schwarz, Baruch and Michael Baker. Dialogue, Argumentation and Education: History, Theory and Practice. Cambridge: Cambridge University Press, 2017.

Siegel, Harvey. Education's Epistemology. Oxford: OUP, 2017.

Snow, Nancy. Virtue as Social Intelligence: An Empirically Grounded Theory. London: Routledge, 2010.

Snow, Nancy. "From "Ordinary" Virtue to Aristotelian Virtue." In Harrison T. and Walker, D. (eds.), The Theory and Practice of Virtue Education (pp.132-149). London, Routledge, 2018.

Stichter, Matt. "Virtues, Skills and Right Action." Ethical Theory and Moral Practice 14 (2011): 73-86.

Sunstein, Cass. Infotopia. Oxford: OUP, 2006. 
Whelan, Frederick. Democracy in Theory and Practice. London: Routledge, 2019.

Whitcomb, Dennis, Heather Battaly, Jason Baehr and Daniel Howards-Snyder. "Intellectual Humility: Owning our limitations." Philosophy and Phenomenological Research 94(3) (2017): 509-539.

Winch, Christopher. Education, Autonomy and Critical Thinking. London: Routledge, 2006.

Wood, Thomas and Ethan Porter. “The Elusive Backfire Effect: Mass Attitudes' Steadfast Factual Adherence." Political Behaviour 41 (2019):135-163.

Wood, Wendy. Good Habits, Bad Habits: The Science of Making Positive Changes that Stick. London: Macmillan, 2019.

Zagzebski, Linda. Virtues of the Mind. Cambridge: Cambridge University Press, 1996. 